\title{
Strategie rozwiązywania konfliktów stosowane przez żony mężczyzn uzależnionych od alkoholu
}

\author{
Strategies for solving conflicts used by wives \\ of men addicted to alcohol
}

\begin{abstract}
Abstrakt
Celem artykułu jest przedstawienie strategii rozwiązywania konfliktów w sytuacji uzależnienia męża od alkoholu. Badaniami objęto kobiety pozostające (obecnie lub w przeszłości) w związku z osobą uzależnioną od alkoholu. Kryterium doboru próby badawczej było zgłoszenie się do placówek pomocowych w związku z problemem alkoholowym w rodzinie. W celu określenia strategii rozwiązywania konfliktów użyto kwestionariusza Strategie Rozwiązywania Konfliktów (SRK), metoda została skonstruowana przez Kriegelewicz (2003) na bazie narzędzia Patterns of Problem Solving autorów: Rusbult, Johnsona i Morrowa (1986). Kwestionariusz SRK mierzy cztery sposoby reagowania na sytuacje konfliktowe w parze małżeńskiej: dialog, lojalność, eskalacja konfliktu, wycofanie. Powyższe strategie będą analizowane $z$ uwzględnieniem takich zmiennych podmiotowych jak: inteligencja emocjonalna, poczucie koherencji, poczucie bezpieczeństwa i prężności osobowej oraz przekonań osobistych. W artykule strategie rozwiązywania konfliktów będą traktowane jako jeden z wyznaczników sposobów adaptacji do sytuacji rodzinnej, które są zmienną określającą prezentowany możliwy wzorzec współuzależnienia, który nie jest jednolitym schematem. Funkcjonowanie w relacji z osobą uzależnioną od alkoholu powoduje zmiany w charakterze relacji, jakości komunikacji między małżonkami wskutek nasilających się sytuacji konfliktowych. Nagromadzone negatywne emocje wskutek wielu doświadczeń zranień, sytuacji przemocowych, obciążeń obowiązkami rodzinnymi niepijącego małżonka powodują wraz z rozwojem uzależnienia stosowanie destruktywnych strategii rozwiązywania konfliktów. Przedstawione wyniki ukazały zróżnicowanie w sposobach rozwiązywania konfliktów przez kobiety współuzależnione zależne od zmiennych sytuacyjnych podmiotowych. Wyniki badań mogą być pomocne w tworzeniu celów terapeutycznych ukierunkowanych na wzmacnianie strategii konstruktywnych oraz wyciszanie i zmianę strategii destruktywnych. Wnioski te wkomponowują się w tendencje w lecznictwie odwykowym ukierunkowane na zmiany i pomoc parze w ramach krótkoterminowej terapii par.
\end{abstract}

Słowa kluczowe: uzależnienie od alkoholu, partnerzy osób uzależnionych od alkoholu, rodzina alkoholowa, współuzależnienie, konflikty, strategie rozwiązywania konfliktów

\section{Wprowadzenie}

W pracy terapeutycznej z kobietami współuzależnionymi obserwuje się różnorodne zmiany w zachowaniu, będące niewątpliwie konsekwencją wpływu uzależnienia od alkoholu partnera na funkcjonowanie całego systemu rodzinnego. Pogorszeniu ulega funkcjonowanie parterów osób współuzależnionych 
w najważniejszych obszarach życia: rodzinnego (relacje), zawodowego, społecznego oraz emocjonalnego (Dawson i in., 2007; Hudson i in., 2014). Doświadczenia zawodowe autorki pokazały, że często codzienną rzeczywistością dla rodzin z problemem uzależnienia stają się sytuacje konfliktowe wynikające z zaburzonych wzorców komunikacyjnych. W związku z rozwojem uzależnienia od alkoholu o charakterze przewlekłym i postępującym następuje narastanie negatywnych emocji między parterami oraz tendencja do ich tłumienia z obawy, że mogą nasilić sytuacje związane z sięganiem po alkohol. Te refleksje skłoniły autorkę do podjęcia badań w kierunku poszukiwania najczęściej stosowanych strategii rozwiązywania konfliktów przez osoby współuzależnione. Placówki specjalistyczne świadczą pomoc skierowaną nie tylko do osób uzależnionych, ale również do partnerów osób uzależnionych oraz dzieci z rodzin z problemem uzależnienia. Nowym trendem w tym obszarze są oddziaływania skierowane do par pozostających w procesie leczenia uzależnienia. Cele stworzonego programu „Krótkoterminowa Terapia Par - proces zdrowienia w uzależnieniu" koncentrują się również na poprawie funkcjonowania pary oraz rodziny jako całości. W tym aspekcie autorzy programu, tj. dr hab. Barbara Bętkowska-Korpała, dr Krzysztof Gąsior, mgr Bożena Maciek-Haściło oraz mgr Jolanta Ryniak uwzględniają potrzeby każdego z partnerów relacji z perspektywy potrzeby niezależności (autonomii) oraz zależności (przynależności, wspólnotowości) (Bętkowska-Korpała i in., 2016). Terapia par, wzmacnianie i usprawnianie wspólnej komunikacji w celu zmniejszania strategii destrukcyjnych rozwiązywania konfliktów jest zasobem w procesie zdrowienia całego systemu (Ryniak i Bętkowska-Korpała, 2013).

Zmiany, jakie wprowadza do rodziny osoba uzależniona od alkoholu, wpływają na wszystkich domowników, powodując konieczność stworzenia nowych zasad rodzinnych (Brown, 1990; Wegscheider, 1981; Wegscheider-Cruse, 1984). Taka sytuacja związana jest z procesem adaptacji do sytuacji rodzinnej warunkującej względną stabilność i równowagę w zachwianym przez nadużywanie alkoholu systemie rodzinnym (por. Cierpiałkowska, 1997). Powołując się na wnioski z badań Steinglassa (1980), należy wspomnieć o tzw. systemie alkoholowym w kontekście roli, jaką odgrywa fakt nadużywania alkoholu przez członka rodziny na zmiany w regułach umożliwiających homeostazę w rodzinie. Stworzony przez Steinglassa i współpracowników $(1980,1985)$ model historii życia rodzin z problemem alkoholowym ukazuje podwójną rolę, jaką odgrywa nadużywanie alkoholu przez członka rodziny. Można spodziewać się, że zasady i wzajemne relacje w systemie rodzinnym są w znacznej mierze przekształcane, wskutek czego powstaje nowy układ interakcji i zależności rodzinnych. Zmienia się cały kontekst, co oznacza, że zmieniają się granice rodziny, role i obowiązki każdego z domowników oraz proces komunikowania się. W myśl tego założenia istnieją sytuacje, w których fakt spożywania alkoholu przez członka rodziny może pełnić rolę sygnalizującą, iż dana rodzina przeżywa jakiś kryzys lub pozostaje pod działaniem stresu. Wówczas paradoksalnie nadużywanie alkoholu pełni funkcje komunikującą o sytuacji problemowej w systemie rodzinnym, rzadko przy tym przeradzając się w uzależnienie (Steinglass i in., 1971). W przypadku gdy u osoby pojawi się już zespół uzależnienia od alkoholu, niejednokrotnie rodzina zaczyna również zmieniać wypracowany do tej pory system rodzinny na taki, który z jednej 
strony umożliwia jej względną stabilność poprzez zachowania służące radzeniu sobie z sytuacją trudną, a z drugiej strony tworzy się schemat działań podtrzymujących nadużywanie alkoholu. W tym wypadku nadużywanie alkoholu przywraca równowagę oraz wzmacnia relacje między partnerami. Badania poczynione przez Steinglassa (1977) wykazały, że funkcjonowanie rodziny z problemem alkoholowych zależy od okresów abstynencji alkoholowej oraz etapów w rozwoju rodziny. Oznacza to, że „wzorce komunikacji zmieniają się w zależności od tego, czy alkoholik pije, czy powstrzymuje się od używania alkoholu" (Cierpiałkowska i Ziarko, 2010, s. 231). W alkoholowych systemach rodzinnych uzależnienie reorganizuje funkcjonowanie rodziny, wpływając na pełnione role, stawiane granice oraz sposoby komunikowania się. Zmiany występujące w różnych obszarach funkcjonowania mają na celu przywrócenie homeostazy w systemie i zwykle cechuje je trwałość oraz opór przed wprowadzaniem zmian (por. Cierpiałkowska i Ziarko, 2010). Wobec powyższego przyjmuje się, że pomocą specjalistyczną winna być objęta również cała rodzina wskutek zaburzonych interakcji w systemie (por. Namysłowska, 2000; Czabała, 2000; Cierpiałkowska, 2005).

Ponadto w rodzinach, w których przynajmniej jeden rodzic jest uzależniony, pojawiają się zaburzone relacje małżeńskie i rodzinne, których negatywny wpływ oddziałuje przede wszystkim na dzieci. W takich rodzinach częściej dochodzi do konfliktów między małżonkami, które z czasem mogą przerodzić się w przemoc (por. Grzegorzewska, 2008, Bays, 1990; Weinberg, 1997). Według Leonarda (1990) nadużywanie alkoholu przez domownika koreluje z wysokim poziomem konfliktów między małżonkami, które z kolei wpływają na zachwianie systemu rodzinnego (El-Sheikh i Flanagan, 2001).

Prekursorem pojęcia definiowanego jako współuzależnienie był Cermak (1986), który starał się dookreślić kryteria diagnostyczne w książce Diagnostyczne kryteria współuzależnienia (Timmen i Cermak, 1986). Od samego początku wokół zagadnienia współuzależnienia pojawiało się wiele niejasności i trudności diagnostycznych podejmowanych również przez kolejnych badaczy, którzy podkreślali, że współuzależnienie nie jest jasnym i ściśle określonym symptomem, lecz jawi się w kilku wzorcach zachowań (Sękowska, 1997; Krawczinska 2007a, 2007b). Różne definicje współuzależnienia akcentują bądź przyczyny tego zjawiska, bądź skutki, jakie powoduje w funkcjonowaniu, inne - stan ogólny, jego objawy lub wzorce zachowań. Brak jasności w definiowaniu tego pojęcia związany jest ze specyfiką złożonego, trudnego do sprecyzowania stanu, jakim jest współuzależnienie. Obecnie wyróżnia się trzy modele opisujące współuzależnienie jako:

- model psychopatologiczny - współuzależnienie jako choroba,

- model zaburzeń osobowościowych,

- model adaptacyjny - współuzależnienie jako reakcja na stres.

W swoich badaniach przyjęłam koncepcję traktującą współuzależnienie jako reakcję przystosowania do sytuacji długotrwałego stresu. Podwalinami tego nurtu jest traktowanie współuzależnienia jako specyficznej reakcji na pozostawanie w związku z osobą uzależnioną. Wobec powyższego zachowania żon alkoholików chroniące uzależnienie męża są pojmowane jako nieefektywne strategie radzenia sobie z sytuacjami problemowymi w rodzinie. 
Sposób postępowania alkoholika spełnia rolę stresora dla członków jego rodziny, co powoduje, że współuzależnienie jest sposobem przetrwania w sytuacji, której stale doświadczają (Bradshaw, 1998). Osoba uzależniona niszczy poczucie bezpieczeństwa domowników, narażając ich na stałe działanie stresu, co z kolei powoduje uformowanie w nich postawy obronnej umożliwiającej przystosowanie. Obciążenia sytuacjami stresowymi i napięciami otoczenia alkoholika są efektem nadużywania przez niego alkoholu (Brown, 1995). Sytuacja związana z uzależnieniem osoby bliskiej sprawia, że rodzina rozwija w sobie różnorodne mechanizmy ułatwiające adaptację do zaistniałej sytuacji.

Traktowanie współuzależnienia jako procesu adaptacji do chronicznej sytuacji stresowej jest często prezentowane również na polskim gruncie. Do reprezentantów tego nurtu niewątpliwie można zaliczyć Jerzego Mellibrudę i Zofię Sobolewską. Według autorów współuzależnienie to „utrwalona forma uczestnictwa długotrwałej i trudnej lub niszczącej sytuacji życiowej związanej z patologicznymi zachowaniami partnera, ograniczająca w sposób istotny swobodę wyboru postępowania, która prowadzi do pogorszenia własnego stanu oraz utrudnia zmianę własnego położenia na lepsze" (Mellibruda i Sobolewska, 1997, s. 1). Oznacza to, że osoba współuzależniona to zwykle parter osoby uzależnionej, czyli osoba, która dobrowolnie weszła w związek, współtworzy go i może z niego wyjść, choć $z$ wielkimi trudnościami. Odniesienie nawiązujące do sytuacji stresowej i mechanizmów adaptacyjnych pojawiających się w związku z syndromem współuzależnienia wyraża się w definicji mówiącej, że jest to „sposób reagowania na silnie stresową sytuację współżycia z alkoholikiem, bądź inną osobą działającą destrukcyjnie, który powoduje swoiste uwikłanie (Kiehne i in.; za: Cierpiałkowska, 2000, s. 90).

Szczepańska (1992) jest kolejną przedstawicielką nurtu ujmującego współuzależnienie jako reakcję na stres związany z życiem z alkoholikiem. Traktuje ona zachowania żon alkoholików jako te, które „występują wyraźnie w związku z sytuacją zewnętrzną, a ich nasilenie zmienia się wraz ze zmianą tej sytuacji" (Szczepańska, 1992, s. 55). Potwierdzeniem tego mogą być wyniki badań ujawniających zmiany w zachowaniu żon alkoholików pod wpływem terapii oraz abstynencji alkoholowej męża (Troise, 1995; Rotunda i Doman, 2001; Oxford, i in., 1975, s. 1254-1267).

Konsekwencją funkcjonowania w sytuacji stresu przewlekłego może być przeciążenie i zaburzenie mechanizmów przystosowawczych występujących u danej osoby. Wówczas pojawić się mogą zachowania i emocje, które są wywołane wyolbrzymionym mechanizmem adaptacyjnym, mającym za zadanie utrzymanie równowagi w systemie, jakim niewątpliwie jest rodzina.

\section{Materiał i metody}

W badaniach wzięło udział 198 kobiet współuzależnionych, które zgłosiły się do placówek i korzystały z ich pomocy w związku z problemem alkoholowym męża. W ramach oddziaływań pomocowych korzystały $z$ różnych form terapii 
indywidualnej i grupowej skierowanej do osób współuzależnionych i były na różnym etapie leczenia. Kryterium doboru było pozostawanie obecnie w związku małżeńskim (170 osób) lub w przeszłości funkcjonowanie w takim związku z osobą uzależnioną od alkoholu. W badaniu wobec powyższego wzięły udział również: wdowy (trzy osoby), rozwódki (13 osób) i kobiety pozostające w separacji (12 osób). Analizowano również sytuację rodzinną badanych kobiet. Omawiając kryterium stażu małżeńskiego, w próbie stwierdzono szeroki zakres stażu od kilku miesięcy do 45 lat wspólnego życia. W zdecydowanej większości rodziny z problemem alkoholowym posiadały dwoje dzieci $(N=90)$, około $1 / 4$ miała jedno dziecko $(\mathrm{N}=48)$, a resztę stanowiły rodziny mające troje lub więcej dzieci.

Badania przeprowadzono w kilkunastu miastach w Polsce w województwach: małopolskim, lubelskim, łódzkim, mazowieckim, wielkopolskim i śląskim. Kobiety te były w zdecydowanej większości mieszkankami miast (124 osoby), tylko 74 pochodziły z terenów wiejskich. Średnia wieku kobiet wynosiła 44,86 lat, a rozpiętość wieku zawierała się w przedziale od 25 do 73 lat. Większość żon alkoholików posiadała wykształcenie średnie (96 osób), około $1 / 4$ badanych miała wykształcenie wyższe (57 osób). Były one aktywne zawodowo (ok. 68\%), i tylko około $32 \%$ to osoby bezrobotne i przebywające na emeryturze bądź rencie, posiadające tym samym własny dochód. Można wnosić, że powyższa prawidłowość przekłada się na sytuację materialną rodzin osób badanych, która określana jest jako: u ponad połowy badanych $(56,1 \%)$ przeciętna, u około $1 / 3$ dobra i tylko u 23 trudna.

W przeprowadzonych analizach uwzględniono również kontekst sytuacyjny problemu i terapii partnera uzależnionego od alkoholu. Czas trwania problemu alkoholowego męża w badanej grupie u około 1/3 wynosił od 10 do 19 lat (77 kobiet), u 56 badanych kobiet problem uzależnienia męża wynosił od kilku miesięcy do 9 lat. W badaniach pojawiła się tendencja, że wraz z czasem trwania problemu alkoholowego męża wzrasta liczba kobiet zwracających się po pomoc specjalistyczną. W badanej grupie objęta leczeniem była grupa 93 mężów, większość jednak nie korzystała z poradnictwa specjalistycznego w związku z problemem alkoholowym własnym - 105 osób.

W badaniu użyto następujących narzędzi badawczych: INTE - Kwestionariusz Inteligencji Emocjonalnej, SOC-29 - Kwestionariusz Orientacji Życiowej, KPB-PO - Kwestionariusz Poczucia Bezpieczeństwa i Prężności Osobowej, KPO - Kwestionariusz Przekonania Osobiste, KSR-UM - Sposoby Reagowania na Uzależnienie Męża od Alkoholu, SRK - Strategie Rozwiązywania Konfliktów (samopis K).

Kwestionariusz Inteligencji Emocjonalnej INTE jest metodą mającą zastosowanie w pomiarze inteligencji emocjonalnej, a jego autorami są: Schutte, Malouff, Hall, Haggerty, Cooper, Golden i Dornheim. Zastosowanie kwestionariusza INTE umożliwia uzyskanie trzech wskaźników liczbowych, na który składają się: wynik ogólny i dwa osobne wyniki czynnikowe: Czynnik I - odzwierciedla zdolność do wykorzystywania emocji w celu wspomagania myślenia i działania; Czynnik II - określa zdolność do rozpoznawania emocji.

Kwestionariusz Orientacji Życiowej (The Sense of Coherence Questionnaire) SOC-29 został opublikowany w 1983 roku przez A. Antonovsky'ego. Kwestionariusz nie posiada polskiej normalizacji, natomiast polska adaptacja została 
wykonana przez kilka zespołów: z Zakładu Psychologii Klinicznej IPiN w Warszawie, Zakładu Psychoprofilaktyki Instytutu Psychologii UAM w Poznaniu oraz Zakładu Psychologii Pracy IMP w Łodzi. Na podstawie tego kwestionariusza możliwe jest obliczenia wyniku ogólnego poczucia koherencji, jak również wyodrębnienie trzech komponentów strukturalnych: poczucia zrozumiałości, poczucia zaradności i poczucia sensowności (Antonovsky, 1996).

Kwestionariusz Poczucia Bezpieczeństwa i Prężności Osobowej w opracowaniu Uchnasta powstał na bazie Kwestionariusza "Security-Insecurity Inventory” (S-I) Maslowa i Skali Prężności-Ego (ER) Blocka (Uchnast, 1990). Przy pomocy kwestionariusza można dokonać pomiaru 5 czynników podstawowych KPB - czynnik bliskości, stabilności, zaufania do siebie, upośredniony wskaźnik poczucia bezpieczeństwa oraz prężność osobowa (Uchnast, 1997, 1998).

Kwestionariusz Strategii Rozwiązywania Konfliktów (SRK) przeznaczony jest do badania stosowanych strategii rozwiązywania konfliktów w parze małżeńskiej. Metoda została skonstruowana przez Kriegelewicz (2003) na bazie narzędzia Patterns of Problem Solving autorów: Rusbult, Johnsona i Morrowa (1986). Za podstawę kwestionariusza przyjęto model strategii rozwiązywania konfliktów w bliskich związkach (Rusbult i in, 1986). Powyższa typologia wyróżnia dwa wymiary reakcji na niezadowolenie w związku (konstruktywność - destruktywność oraz aktywność - bierność) oraz czterech strategii rozwiązywania konfliktów, które powstały z połączenia tych wymiarów:

1. Dialog - strategia konstruktywna i aktywna,

2. Lojalność - strategia konstruktywna i bierna,

3. Eskalacja konfliktu - strategia destruktywna i aktywna,

4. Wycofanie - strategia destruktywna i bierna.

Kwestionariusz Przekonania Osobiste (KPO) jest narzędziem własnego autorstwa, dającym możliwość określenia reprezentowanego spektrum zachowań i przekonań, jakie prezentuje żona alkoholika. Narzędzie składa się z 20 twierdzeń tworzących 5 czynników: nierealistyczny optymizm, lęk przed izolacją społeczną, pragnienie podtrzymania rodziny, niepewność, zależność od męża.

\section{Wyniki}

Przeprowadzone badania poddano analizom statystycznym z zastosowaniem pakietów komputerowych programu SPSS 14.00 oraz Statistica 8.1. (Brzeziński, 1996; 2000).

Strategie rozwiązywania konfliktów w rodzinach własnych przez osoby współuzależnione (cała grupa) oraz należące do wyodrębnionych grup: A (kobiety, których mężowie korzystają z leczenia odwykowego) i B (kobiety, których mężowie nie korzystają z leczenia odwykowego) mierzone za pomocą kwestionariusza SRK prezentuje tabela 1 (wyniki surowe). 
Tabela 1. Średnie (M), odchylenia standardowe (SD) oraz wskaźniki istotności różnic pomiędzy grupami A i B w skalach SRK

\begin{tabular}{|c|c|c|c|c|c|c|c|c|}
\hline \multirow{2}{*}{ Skupy } & \multicolumn{2}{|c|}{ całość } & \multicolumn{2}{c|}{$\begin{array}{c}\text { grupa A } \\
\text { (N = 93) }\end{array}$} & \multicolumn{2}{c|}{$\begin{array}{c}\text { grupa B } \\
\text { (N= 105) }\end{array}$} & \multicolumn{2}{c|}{$\begin{array}{c}\text { t-Studenta } \\
\text { (różnice A i B) }\end{array}$} \\
\cline { 2 - 10 } & M & SD & M & SD & M & SD & t & p \\
\hline Dialog & 20,17 & 7,03 & 20,88 & 6,76 & 19,55 & 7,18 & 1,37 & 0,183 \\
\hline Lojalność & 18,46 & 5,59 & 17,80 & 4,62 & 18,94 & 6,21 & $-1,48$ & 0,139 \\
\hline $\begin{array}{c}\text { Eskalacja } \\
\text { konfliktu }\end{array}$ & 17,82 & 6,28 & 18,05 & 6,36 & 17,68 & 6,23 & 0,42 & 0,674 \\
\hline Wycofanie & 20,70 & 7,31 & 20,91 & 6,44 & 20,55 & 8,03 & 0,35 & 0,729 \\
\hline
\end{tabular}

${ }^{*} \mathrm{p} \leq 0.05 ;{ }^{* *} \mathrm{p} \leq 0.01 ;{ }^{* * *} \mathrm{p} \leq 0.00$

Źródło: opracowanie własne.

Uzyskane wyniki pokazują wiele podobieństw w zakresie stosowanych strategii rozwiązywania konfliktów pomiędzy dwoma grupami kobiet współuzależnionych. Wśród najczęstszych strategii można wyróżnić dwie: Wycofanie i Dialog. Strategia Lojalności uzyskała wyższe wartości średnie w grupie B w porównaniu z grupą A, co oznacza, że kobiety, których mąż nie uczestniczył w terapii, wydają się być bardziej lojalne względem niego, aniżeli kobiety, których mąż uczestniczył w terapii. Dialog u kobiet z grupy A jest nieco wyższy w porównaniu z kobietami z grupy B. Wynika stąd, że kobiety z grupy A wydają się być mniej lojalne wobec męża a bardziej skłonne do dialogu, natomiast kobiety z grupy B ujawniają tendencję odwrotną. Być może różnice te są efektem podjętej terapii odwykowej przez męża i większej skłonności do analizowania własnego problemu w obszarze rodzinnym. W obydwu porównywanych grupach kobiet współuzależnionych na podobnym poziomie mieści się Eskalacja Konfliktu.

Strategie rozwiązywania konfliktów w korelacji z inteligencją emocjonalną przedstawia tabela 2.

Tabela 2. Współczynniki korelacji $r$-Pearsona między wynikami w SRK i INTE w grupie badanych kobiet

\begin{tabular}{|c|c|c|c|}
\hline INTE & $\begin{array}{c}\text { Inteligencja } \\
\text { emocjonalna }\end{array}$ & $\begin{array}{c}\text { Zdolność do wyko- } \\
\text { rzystywania emocji }\end{array}$ & $\begin{array}{c}\text { Zdolność } \\
\text { do rozpoznawania } \\
\text { emocji }\end{array}$ \\
\hline Dialog & $0,33^{* *}$ & $0,30^{* *}$ & $0,30^{* *}$ \\
\hline Lojalność & $0,18^{*}$ & $0,15^{*}$ & $0,21^{* *}$ \\
\hline Eskalacja konfliktu & $-0,18$ & $-0,08$ & $-0,10$ \\
\hline Wycofanie & $-0,15^{*}$ & $-0,10$ & $-0,17^{*}$ \\
\hline
\end{tabular}

${ }^{*} \mathrm{p} \leq 0.05 ;{ }^{* *} \mathrm{p} \leq 0.01 ;{ }^{* * *} \mathrm{p} \leq 0.00$

Źródło: opracowanie własne. 
Strategie konstruktywne (Dialog i Lojalność) wykazały istotnie dodatnią korelację z wszystkimi wynikami w skali inteligencji emocjonalnej (Inteligencja Emocjonalna - wynik ogólny, Zdolność do Wykorzystywania Emocji i Zdolność do Rozpoznawania Emocji). Przy czym należy podkreślić, że wyższa siła związków korelacyjnych zachodzi pomiędzy Dialogiem a Inteligencją Emocjonalną i czynnikami wchodzącymi w jej skład. Powyższe zależności oznaczają, że wyższy poziom inteligencji emocjonalnej wpływa na wybór stosowanych konstruktywnych strategii rozwiązywania konfliktów.

Strategia Wycofanie koreluje natomiast ujemnie z Inteligencją Emocjonalną - wynik ogólny i Zdolnością do Rozpoznawania Emocji. Im częściej stosowane jest wycofanie jako sposób reagowania na sytuację konfliktową, tym mniejsza zdolność do rozpoznawania emocji występuje u tej osoby.

Nie stwierdzono istotności związków korelacyjnych pomiędzy nasileniem inteligencji emocjonalnej a strategią Eskalacja Konfliktu.

Strategie rozwiązywania konfliktów w korelacji z poczuciem koherencji przedstawia tabela 3.

Tabela 3. Współczynniki korelacji $r$-Pearsona między wynikami w SRK i SOC-29 w grupie badanych kobiet

\begin{tabular}{|c|c|c|c|c|}
\hline SOC-29 & $\begin{array}{c}\text { Poczucie } \\
\text { koherencji }\end{array}$ & $\begin{array}{c}\text { Poczucie } \\
\text { zrozumiałości }\end{array}$ & $\begin{array}{c}\text { Poczucie } \\
\text { zaradności }\end{array}$ & $\begin{array}{c}\text { Poczucie } \\
\text { sensowności }\end{array}$ \\
\hline Dialog & $0,33^{* *}$ & $0,25^{* *}$ & $0,30^{* *}$ & $0,32^{* *}$ \\
\hline Lojalność & $0,16^{*}$ & 0,13 & $0,18^{* *}$ & 0,08 \\
\hline Eskalacja konfliktu & $-0,23^{* *}$ & $-0,17^{*}$ & $-0,26^{* *}$ & $-0,17^{*}$ \\
\hline Wycofanie & $-0,17^{*}$ & $-0,11$ & $-0,16^{*}$ & $-0,17^{*}$ \\
\hline
\end{tabular}

${ }^{*} p \leq 0.05 ;{ }^{* *} p \leq 0.01 ;{ }^{* * *} p \leq 0.00$

Źródło: opracowanie własne.

Dwie strategie wykazują zależność istotną z Poczuciem Koherencji i wszystkimi jego komponentami. Dialog ujawnił dodatnią korelację z Poczuciem Koherencji i Poczuciem Zrozumiałości, Zaradności i Sensowności. Druga strategia korelująca z wszystkimi wymiarami poczucia koherencji to Eskalacja Konfliktu. Przy czym zależność ta ma charakter ujemny. Powyższe zależności oznaczają, że wyższy poziom poczucia koherencji i jego wymiarów wpływa na wybór dialogu jako stosowanych strategii rozwiązywania konfliktów, natomiast niskie poczucie koherencji wiąże się z wyborem eskalacji konfliktu.

Strategia Lojalności wykazała dodatnią korelację z dwoma skalami: Poczuciem Koherencji i Poczuciem Zaradności. Wyższe poczucie zaradności wiąże się z częstszym stosowaniem strategii lojalności wobec partnera w sytuacji konfliktowej.

Ostatnią ze strategii ujawniająca zależność istotną z trzema wynikami SOC-29 jest strategia Wycofanie. Pomiędzy Wycofaniem a Poczuciem Koherencji, 
Poczuciem Zaradności i Sensowności występuje korelacja ujemna. Oznacza to, że wycofanie jako sposób rozwiązywania konfliktów jest stosowany wówczas, gdy poczucie zaradności i sensowności jest obniżone.

Strategie rozwiązywania konfliktów w korelacji z poczuciem bezpieczeństwa i prężności osobowej przedstawia tabela 4.

Tabela 4. Współczynniki korelacji $r$-Pearsona między wynikami w SRK i KPB-PO w grupie badanych kobiet

\begin{tabular}{|c|c|c|c|c|c|}
\hline KRK & Bliskość & Stabilność & $\begin{array}{c}\text { Zaufanie } \\
\text { do siebie }\end{array}$ & $\begin{array}{c}\text { Poczucie } \\
\text { bezpieczeństwa }\end{array}$ & $\begin{array}{c}\text { Prężność } \\
\text { osobowa }\end{array}$ \\
\hline Dialog & $0,31^{* *}$ & $0,24^{* *}$ & $0,37^{* *}$ & $0,35^{* *}$ & $0,21^{* *}$ \\
\hline Lojalność & 0,13 & $0,15^{*}$ & 0,08 & 0,13 & 0,06 \\
\hline Eskalacja konfliktu & $-0,19^{* *}$ & $-0,39^{* *}$ & $-0,27^{* *}$ & $-0,33^{* *}$ & 0,02 \\
\hline Wycofanie & $-0,11$ & $-0,20^{* *}$ & $-0,18^{*}$ & $-0,19^{* *}$ & $-0,01$ \\
\hline
\end{tabular}

${ }^{*} \mathrm{p} \leq 0.05 ;{ }^{* *} \mathrm{p} \leq 0.01 ;{ }^{* * *} \mathrm{p} \leq 0.00$

Źródło: opracowanie własne.

Zależności istotne statystycznie występują pomiędzy prawie wszystkimi skalami SRK i KPB-PO. Konstruktywne strategie rozwiązywania konfliktów korelują dodatnio z czynnikami Kwestionariusza Poczucia Bezpieczeństwa i Prężności Osobowej. Dialog koreluje ze skalami Bliskości, Stabilności, Zaufania do Siebie, Poczucia Bezpieczeństwa i Prężności Osobowej. Skala Lojalności natomiast ujawniła zależność istotną o charakterze dodatnim ze skalą Stabilności. Oznacza to, że poczucie bezpieczeństwa, zaufania do siebie, bliskości i stabilności wpływa na stosowanie dialogu jako rozwiązania sytuacji konfliktowych.

Korelacje ujemne wystąpiły między skalami destruktywnymi: Eskalacją Konfliktu a Bliskością, Stabilnością, Zaufaniem do Siebie i Poczuciem Bezpieczeństwa. Powiązania o charakterze ujemnym pojawiły się pomiędzy strategią Wycofanie a skalami Stabilności, Zaufania do Siebie i Poczucia Bezpieczeństwa. Obniżone poczucie bezpieczeństwa, zaufania do siebie i stabilności wpływa na ujawnianie destruktywnych sposobów rozwiązywania konfliktów (eskalacji konfliktu i wycofania).

Strategie rozwiązywania konfliktów w korelacji z przekonaniami osobistymi przedstawia tabela 5. 
Tabela 5. Współczynniki korelacji $r$-Pearsona między wynikami w SRK i KPO w grupie badanych kobiet

\begin{tabular}{|c|c|c|c|c|c|}
\hline KRK & $\begin{array}{c}\text { Nierealistyczny } \\
\text { optymizm }\end{array}$ & $\begin{array}{c}\text { Lęk przed } \\
\text { izolacją } \\
\text { społeczną }\end{array}$ & $\begin{array}{c}\text { Pragnienie } \\
\text { podtrzymania } \\
\text { rodziny }\end{array}$ & Niepewność & $\begin{array}{c}\text { Zależność } \\
\text { od męża }\end{array}$ \\
\hline Dialog & 0,06 & $-0,12$ & $-0,17^{*}$ & $-0,14^{*}$ & $-0,16^{*}$ \\
\hline Lojalność & $0,24^{* *}$ & $0,22^{* *}$ & 0,04 & 0,13 & 0,14 \\
\hline $\begin{array}{c}\text { Eskalacja } \\
\text { konfliktu }\end{array}$ & 0,04 & 0,13 & $0,28^{* *}$ & 0,09 & $0,19^{* *}$ \\
\hline Wycofanie & 0,06 & 0,08 & $0,15^{*}$ & 0,13 & $0,15^{*}$ \\
\hline
\end{tabular}

${ }^{*} \mathrm{p} \leq 0.05 ;{ }^{* *} \mathrm{p} \leq 0.01 ;{ }^{* * *} \mathrm{p} \leq 0.00$

Źródło: opracowanie własne.

Strategia Dialog koreluje ujemnie z Pragnieniem Podtrzymania Rodziny, Niepewnością i Zależnością od Męża. Oznacza to, że w sytuacji, gdy kobieta współuzależniona jest zależna od męża, niepewna swojej wartości i za wszelką cenę uważa, że małżeństwo powinno być utrzymane, rzadziej będzie stosować dialog jako strategię rozwiązania nieporozumień.

Strategia Lojalności wykazała zależność o charakterze dodatnim ze skalami: Nierealistyczny Optymizm i Lęk przed Izolacją Społeczną. Obawa przed oceną ze strony otoczenia oraz patrzenie na problem alkoholowy męża w sposób minimalizujący sprawia, że żona częściej będzie lojalna względem niego w sytuacji konfliktowej.

Strategie destruktywne (Eskalacja Konfliktu i Wycofanie) ujawniły dodatnią korelację ze skalami: Pragnienie Podtrzymania Rodziny oraz Zależność od Męża. Im większa zależność od męża oraz chęć ratowania rodziny, tym częściej jest stosowana strategia aktywna potęgująca konflikt lub bierna polegająca na wycofaniu się z relacji z mężem.

\section{Omówienie wyników}

Stosowanie strategii biernych w rozwiązywaniu konfliktów przez żony mężczyzn uzależnionych od alkoholu podyktowane jest funkcjonowaniem w sytuacji stresu przewlekłego. Osoby współuzależnione często doświadczają realnego zagrożenia wywołującego u nich adekwatny do sytuacji lęk i poczucie zagrożenia (Kucińska, 2012). Przyczyną takiego stanu rzeczy są sytuacje związane z zachowaniami przemocowymi, brak stabilności psychicznej, finansowej oraz związanej z pełnionymi przez nich rolami rodzinnymi. Powtarzalność tych zachowań sprzyja utrwaleniu się wzorca wycofania i lojalności w zależności od przyjętych motywów partnerów współuzależnionych. Dzieje się tak, bowiem w początkowych fazach adaptacji do problemu uzależnienia w rodzinie u partnerów przewija się 
motyw nadziei na pozytywne rozwiązanie sytuacji. Wówczas częściej w sytuacji nieporozumień pojawia się strategia lojalności w przekonaniu, że należy przeczekać, że z czasem problem się rozwiąże. Natomiast wskutek długotrwałych konsekwencji funkcjonowania w relacji z osobą uzależnioną może się rozwinąć syndrom wyuczonej bezradności. Sprzyja on niewątpliwie ukształtowaniu się reakcji wycofania i braku działań nawet w sytuacji poczucia zagrożenia. Wyjściem z powyższych wzorców rozwiązywania konfliktów jest podjęcie terapii dla osób współuzależnionych celem skonfrontowania i przepracowania tego, co trudne i bolesne i co wzbudza lęk (Krajczewska i Frąckiewicz, 2013).

Kolejną strategią często stosowaną przez żony mężczyzn uzależnionych od alkoholu jest eskalacja konfliktu. Niewątpliwie efektem przystosowania się do niekonstruktywnych warunków i obciążającej emocjonalnie sytuacji może być tłumienie negatywnych emocji. Zachowania przemocowe, brak szacunku, odpowiedzialności i życie w stanie ciągłego stresu powoduje, że doświadczanie negatywnych emocji u takich osób jest sytuacją poniekąd codzienną. Ponadto, gdy w takiej reakcji nie ma możliwości prowadzenia otwartej, szanującej granice psychologiczne komunikacji, narasta odczuwana frustracja. Wnioski te potwierdzają badania prowadzone przez Instytut Psychologii Zdrowia wśród współuzależnionych kobiet według, których ok. $1 / 2$ przejawiała zachowania o znamionach agresji słownej (Włodawiec, 2000). Jest jeszcze jeden ważny aspekt związany z tendencjami do ujawniania agresji werbalnej w tej grupie. Mianowicie zmiany w zachowaniu partnera uzależnionego w postaci abstynencji, uczestnictwa w terapii powodują, że zaczyna on angażować się w życie rodziny, interesować bieżącymi sprawami. Rodziny osób uzależnionych wraz z rozwojem uzależnienia odwykli jednak od takich sytuacji, gdyż często przyzwyczaiły się, że same muszą działać i podejmować decyzje dotyczące rodziny. Brak oddziaływań i zmian również na płaszczyźnie komunikacyjnej między osobą uzależnioną a jej partnerem staje się źródłem dodatkowych nieporozumień, konfliktów oraz awantur (por. Łuczak, 2010). Jest to kolejny przykład na zasadność wprowadzenia nowych trendów w pracy z rodziną, gdzie jest problem alkoholowy, opierających się na zasadach krótkoterminowej terapii par (Bętkowska-Korpała i in., 2016). Analiza procesów trzeźwienia pokazuje, że sama abstynencja od alkoholu nie zmienia na poziomie mechanizmów i konkretnych zachowań osoby uzależnionej. W sposobie myślenia, zachowania, na poziomie nawyków i działania pozostaje w dalszym stopniu widoczny mechanizm regulowania uczuć i emocji za pomocą reakcji kompulsywnych. Mózg osoby uzależnionej w dalszym ciągu odczuwa potrzebę stymulacji, którą w przypadku braku alkoholu stara się zastąpić innymi doznaniami (m.in. sięganie po inne substancje psychoaktywne, impulsywne i napięciowe zachowania). Kłótnie, nieporozumienia oraz awantury stają się nie tylko sposobem rozładowania napięć wewnętrznych, ale również źródłem mocnych wrażeń i dodatkową stymulacją, co znajduje potwierdzenie również w powyższych badaniach (Zawichrowska, 2016). 


\section{Bibliografia}

Antonovsky A. (1996), Rozwikłanie tajemnicy zdrowia, Fundacja IPN, Warszawa.

Bays J. (1990), Substance abuse and child abuse: Impact of addiction on the child, „Pediatric Clinics of North America" 37, s. 881-904.

Bętkowska-Korpała B. i in., (2016), Krótkoterminowa terapia par. Proces zdrowienia w uzależnieniu, Państwowa Agencja Rozwiązywania Problemów Alkoholowych, Warszawa.

Bradshaw J. (1998), Zrozumieć rodzinę, Polskie Towarzystwo Psychologiczne. Instytut Psychologii Zdrowia i Trzeźwości, Warszawa.

Brown S. (1990), Leczenie alkoholików. Rozwojowy model powrotu do zdrowia, PZWL Wydawnictwo Lekarskie, Warszawa.

Brzeziński J. (1996), Metodologia badań psychologicznych, PWN, Warszawa.

Brzeziński J. (2000), Badania eksperymentalne w psychologii i pedagogice, Wydawnictwo Naukowe PWN, Warszawa.

Cierpiałkowska L. (1997), Alkoholizm. Małżeństwa w procesie leczenia, Wydawnictwo Naukowe UAM, Poznań.

Cierpiałkowska L. (2000), Alkoholizm, przyczyny, leczenie, profilaktyka, Wydawnictwo Naukowe UAM, Poznań.

Cierpiałkowska L. (2005), Koncepcje interakcyjne i systemowe oraz ich znaczenie dla psychologii klinicznej, [w:] H. Sęk (red.), Psychologia kliniczna, t. 1, Wydawnictwo Naukowe PWN, Warszawa, s. $132-152$.

Cierpiałkowska L., Ziarko M. (2010), Psychologia uzależnień - alkoholizm, Wydawnictwa Akademickie i Profesjonalne, Warszawa.

Czabała J.C. (2000), Czynniki leczące w psychoterapii, Wydawnictwo Naukowe PWN, Warszawa.

Dawson D.A. i in. (2007), The impact of partner alcohol problems on women's physical and mental health, „Journal of Psychoactive Drugs” 68(1), s. 66-75.

El-Sheikh M. i Flanagan E. (2001), Parental problem drinking and children's adjustment: Family conflict and parental depression as mediators and moderator of risk, „Journal of Abnormal Child Psychology" 10, s. 36-42.

Gąsior K. (2013), Rodzina w terapii, „Terapia Uzależnienia i Współuzależnienia” 2, s. 4-6.

Grzegorzewska I. (2008), Czynniki ryzyka i ochrony w przebiegu rozwoju dzieci alkoholików, [w:] L. Cierpiałkowska (red.), Oblicza współczesnych uzależnień, Wydawnictwo Naukowe UAM, Poznań, s. 258-277.

Hudson C. i in. (2014), Social adjustment of women with and without a substance-abusing partner, „Journal of Psychoactive Drugs” 46(2), s. 106-113.

Jaworowska A., Matczak A. (2008), Kwestionariusz Inteligencji Emocjonalnej INTE. Podręcznik, Pracownia Testów Psychologicznych, Warszawa.

Jelonkiewicz I., Kosińska-Dec K. (2001), Poczucie koherencji a style radzenia sobie ze stresem: empiryczna analiza kierunku zależności, „Przegląd Psychologiczny” 3, s. 337-347.

Krajczewska L., Frąckiewicz E. (2013), Bajka i teatr w terapii współuzależnienia, „Terapia Uzależnienia i Współuzależnienia" 5, s. 31-34.

Krawczinska D. (2007a), Czym jest współuzależnienie, krótka próba rekonstrukcji potocznego rozumienia pojęcia, „Problemy Narkomanii” 2, s. 73-78.

Krawczinska D. (2007b), Choroba, zaburzenie, reakcja na stres, czy...? W poszukiwaniu definicji współuzależnienia w rodzinie z problemem uzależnienia dziecka od narkomanii, „Problemy Narkomanii" 4, s. 5-29.

Kriegelewicz O. (2003), Kwestionariusz do badania strategii rozwiązywania konfliktów w parze małżeńskiej, „Nowiny Psychologiczne” 4, s. 15-31.

Kucińska M. (2012), Praca z lękiem występującym u osób współuzależnionych, „Terapia Uzależnienia i Współuzależnienia" 2, s. 15-17.

Leonard K.E. (1990), Marital functioning among episodic and steady alcoholics, [w:] R.L. Collins, K.E. Leonard, J.S. Searles (red.), Alcohol and the family: Research and clinical perspectives, Guilford Press, New York, s. 220-243. 
Łuczak E. (2010), Współuzależnienie jako problem jednostkowy i społeczny, [w:] D. Wajsprych (red.), Przekraczanie kręgu ubóstwa kulturowego. Konteksty społeczne, Oficyna Wydawnicza „Impuls”, Kraków, s. 43-49.

Namysłowska I. (2000), Terapia rodzin, Instytut Psychiatrii i Neurologii, Warszawa.

Oxford J. i in. (1975), Self-reported doping behavior of wives of alcoholics and its association with drinking outcome, „Journal of Studies on Alcohol” 36, s. 1254-1267.

Rusbult C.E., Johnson D.J., Morrow G.D. (1986), Impact of couple patterns of problem solving on distress and nondistress in dating relationships, „Journal of Personality and Social Psychology” 50(4), s. 744-753.

Ryniak J., Bętkowska-Korpała B. (2013), Para w kontekście leczenia uzależnienia - pierwszy kontakt i wyznaczanie kierunków terapii, „Świat Problemów” 4, s. 9-14.

Steinglass P. (1977), Experimenting with family treatment approaches to alcoholism. 1950-1975: A review, „Family Process” 15, s. 97-123.

Steinglass P. (1980), A life history model of the alcoholic family, „Family Process” 19, s. 211-226.

Steinglass P., Tislenko L., Reiss D. (1985), Stability/instability in the alcoholic marriage: The interrelationships between course of alcoholism, family process and marital outcome, „Family Process” 24, s. 365-376.

Steinglass P., Weiner S., Mendelson J.H. (1971), A system approach to alcoholism: A model and its clinical application, „Archives of General Psychiatry” 24, s. 401-408.

Szczukiewicz P. (2013), System rodzinny a pomaganie osobom uzależnionym, „Terapia Uzależnienia i Współuzależnienia" 2, s. 7-11.

Szczukiewicz P. (2015), Uzależnienie psychiczne, „Terapia Uzależnienia i Współuzależnienia” 2, s. 7-9.

Timmen L., Cermak M.D. (1986), Diagnosing and treating co-dependence, Johnson Institute, Ohms Lane.

Uchnast Z. (1990), Metoda pomiaru poczucia bezpieczeństwa, [w:] A. Januszewski, Z. Uchnast, T. Witkowski (red.), Wykłady z psychologii w KUL, t. 5, RW KUL, Lublin, s. 95-108.

Uchnast Z. (1997), Prężność osobowa. Empiryczna typologia i metoda pomiaru, „Roczniki Filozoficzne TN KUL" 45(4), s. 25-51.

Uchnast Z. (1998), Prężność osobowa a egzystencjalne wymiary wartościowania, „Roczniki Psychologiczne TN KUL" 1, s. 7-27.

Wegscheider S. (1981), Another change. Hope and health for alcoholic family, Science and Behavior Boooks, Palo Alto.

Wegscheider-Cruse S. (1984), Co-dependency: The therapeutic void. Co-dependency: An Emerging Issue, Health Communications, Hollywood.

Weinberg N.Z. (1997), Developmental effects of parental alcohol use, [w:] N. Alessi (red.), Handbook of Child and Adolescent Psychiatry, vol. 4, John Wiley-Sons, New York, s. 171-187.

Włodawiec B. (2000), W rodzinach współuzależnionych kobiet, „Świat Problemów” 10, s. 85.

Zawichrowska M. (2016), „Ciebie kocham, ale Twojego picia nie...”. Kobieta na karuzeli życia - jak pokonać współuzależnienie?, [w:] H. Liberska, A. Malina, D. Suwalska-Barancewicz (red.), Zmiany w życiu współczesnych ludzi i ich konteksty, Difin SA, Warszawa.

\section{Abstract}

Introduction: The aim of the article is to present conflict resolution strategies in dealing with alcohol addiction of the husband. The study involved women who are (or were) in a relationship with a person addicted to alcohol. The criterion for the selection of the research sample was to apply to aid institutions in connection with an alcohol problem in the family. In order to determine the conflict resolution strategy, the Strategy for Conflict Resolution Strategy (SRK) was used. The method was constructed by Kriegelewicz (2003), based on the "Patterns of Problem Solving" tool by Rusbult, Johnson and Morrow (1986). The SRK questionnaire measures four ways of responding to conflict situations in marriage: dialogue, loyalty, escalation of the conflict, withdrawal. The above strategies will be analyzed with consideration for such subject variables as: emotional intelligence, sense of coherence, sense of security and resilience as well as personal beliefs. In the article, strategies for resolving conflicts will be treated as one of the determinants of the methods of adaptation to the family situation, which constitute 
a variable defining the presented potential pattern of co-dependency that is not uniform. Functioning in a relationship with a person addicted to alcohol causes changes in the nature of relationships and the quality of communication between spouses, as a result of intensifying conflict situations. The accumulated negative emotions resulting from emotional pain, instances of violence, as well as the burden of family duties on the non-drinking spouse, lead to destructive conflict resolution strategies along with the development of addiction. The presented results show differences in ways of solving conflicts by co-addicted women, depending on situational and subjective variables. The results of the research may be helpful in creating therapeutic goals aimed at strengthening constructive strategies, as well as silencing and changing destructive strategies. These conclusions fit into rehabilitation trends directed at helping couples as part of short-term therapy.

Keywords: alcohol addiction, partners of people addicted to alcohol; alcohol family, co-dependency, conflicts, conflict resolution strategies 